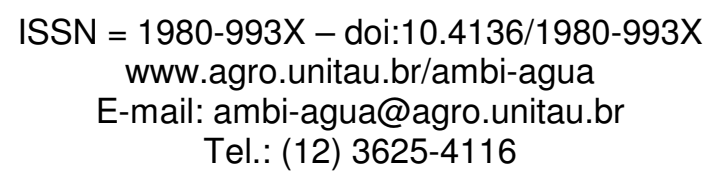

\title{
Decrease in carbon stocks in an oxisol due to land use and cover change in southwestern Amazon
}

(doi:10.4136/ambi-agua.86)

\author{
Cleber Ibraim Salimon ${ }^{1}$; Paulo Guilherme Salvador Wadt ${ }^{2}$; Suhelen de Souza Alves ${ }^{1}$ \\ ${ }^{1}$ Universidade Federal do Acre \\ E-mail: clebsal@gmail.com; su@dris.com.br \\ ${ }^{2}$ Embrapa Acre \\ E-mail: paulo@cpafac.embrapa.br
}

\begin{abstract}
This study presents data on the influence of the land cover type on soil carbon stocks in an Oxisol in southwestern Amazon, Acre, Brazil, under three land cover types: mature forest, pasture and rubber tree plantation. Total soil carbon was calculated using carbon concentration in soil and soil bulk density. Accumulated soil carbon stock up to $1 \mathrm{~m}$ depth was greater in mature forest $\left(96 \mathrm{Mg} \mathrm{ha}^{-1}\right)$, followed by pasture $\left(79.7 \mathrm{Mg} \mathrm{ha}^{-1}\right)$ and then by rubber tree plantation $\left(56.3 \mathrm{Mg} \mathrm{ha}^{-1}\right)$; also the greatest carbon accumulation in the surface layers was in pasture. Such results demonstrate that we need not only carbon stocks information by soil type, but also precise information on the land cover classification within a region in order to generate better soil carbon stocks estimations. Also, it is important to notice that mature forest conversion to other land covers can be the source to the atmosphere of about 20 to $40 \%$ of the carbon stocked in the soil previously.
\end{abstract}

Keywords: soil carbon; Amazon; land cover change; climatic change.

\section{Diminuição nos estoques de carbono em um latossolo devido à mudança de cobertura e uso da terra no sudoeste da Amazônia}

\section{RESUMO}

O objetivo do presente trabalho foi avaliar o efeito da mudança de cobertura do solo sobre os estoques de carbono em um Argissolo Vermelho Amarelo no sudoeste da Amazônia brasileira (Acre) sob três tipos de uso da terra: floresta, pastagem e cultivo de seringueira. A quantidade total de carbono por volume de solo foi calculada pelo teor de carbono e a densidade aparente do solo. $\mathrm{O}$ estoque de carbono acumulado até a profundidade de $1 \mathrm{~m}$ foi maior para solos sob floresta $\left(96 \mathrm{Mg} \mathrm{ha}^{-1}\right)$, seguido por pastagem $\left(79,7 \mathrm{Mg} \mathrm{ha}^{-1}\right.$ ) e por cultivo perene de seringueira $\left(56,3 \mathrm{Mg} \mathrm{ha}^{-1}\right)$ e o maior acúmulo superficial foi em pastagens. Tais resultados demonstram que necessitamos, além do estoque por tipo de solo, de informações mais precisas sobre os tipos de cobertura para se fazer estimativas regionais de estoque de carbono mais confiáveis e reais. Deve-se observar também que com a conversão de floresta madura para outras coberturas, pode ser uma fonte para a atmosfera de cerca de 20 a $40 \%$ do carbono armazenado previamente.

Palavras-chave: carbono no solo; Amazônia; mudança de cobertura da terra; mudanças climáticas. 
SALIMON, C. I.; WADT, P. G. S.; ALVES, S. S. Decrease in carbon stocks in an oxisol due to land use and cover change in southwestern Amazon. Ambi-Agua, Taubaté, v. 4, n. 2, p. 57-65, 2009. (doi:10.4136/ambiagua.86)

\section{INTRODUCTION}

Global estimates for soil carbon stocks usually present little accuracy because of (a) high spatial variability in soil carbon stocks; (b) lack of precision on the extent of each soil type; (c) sampling errors, particularly when estimating soil bulk density, and (d) the effect of land cover change (Eswaran et al., 1993).

The dynamic carbon balance at the planet's surface is a function of the interaction among its reservoirs (such as oceans, terrestrial ecosystems and atmosphere), mainly through carbon dioxide fluxes (Schlesinger, 1997).

In terrestrial ecosystems, about half of the carbon can be found as soil organic matter, which is also an important $\mathrm{C}$ reservoir (Brady and Weil, 1999). Oxisols represent $8.7 \%$ of Earth's solid surface, and being mostly concentrated in tropical regions, storing approximately $7.5 \%$ of all the soil carbon content, down to a depth of $1 \mathrm{~m}$ (Eswaran et al., 1993).

In cultivated areas, the organic matter content tends to decrease, since the organic fractions are more exposed to decomposers due to till and other management practices. The amount of organic carbon loss in cultivated soils will depend not only on the type of soil, but also on the different practices and their intensity. This loss will also depend the amount and quality of carbon stored prior to the change in the land cover, such as if mature forest, savannah or pasture, for instance.

Carvalho et al. (2002), while studying a forest to pasture chronosequence, found for forest a total soil carbon stock of $30 \mathrm{Mg} \mathrm{ha}^{-1}$ down to $30 \mathrm{~cm}$ depth, and for pasture (Brachiaria brizantha) $50 \mathrm{Mg} \mathrm{ha}^{-1}$. They have also observed that $\mathrm{C} / \mathrm{N}$ and lignin/cellulose ratio on litter and roots are also important factors that are related to soil carbon stocks after deforestation, since this will determine among other factors, how labile and how fast the carbon in the soil can be respired by decomposers and then resulting in carbon losses in the system.

Cerri et al. (1999) state that $\mathrm{C}$ stored in the soil surface horizons is the most labile and therefore more sensitive to alteration after land cover change, as in forest to pasture conversion. Salimon et al. (2004) have also found that about $50 \%$ of the C stocked and almost all the $\mathrm{C}$ being respired in pasture soil have a $\delta^{13} \mathrm{C}$ of $\mathrm{C} 4$ grasses, demonstrating that on these 12-14 year old pastures, most of the active carbon is pasture derived.

Beside these studies, there are few other soil carbon stocks estimates for different soil types or land cover types in the Amazon. One can find a considerable amount of data on carbon concentration in the soil, but since most of these data are not associated with soil bulk density, they are not useful for carbon stocks estimation.

In order to solve this "lack of soil density" problem, some authors have proposed some mathematical models, based on empirical allometric relationships) which aim to estimate soil bulk density from other more frequently available data (Bernoux, 1998; Manrique andJones, 1991).

For such purpose, soil carbon stocks are a function of the difference between the amount of $\mathrm{C}$ added $\left(\mathrm{k}_{1} \mathrm{~A}\right)$ and lost $\left(-\mathrm{k}_{2} \mathrm{C}\right)$, and this variation is expressed by the equation $\mathrm{dC} / \mathrm{dt}=\mathrm{k}_{1}$. A$\mathrm{k}_{2}$. $\mathrm{C}$, where " $\mathrm{A}$ " represents photosynthesized $\mathrm{C}$ added and $\mathrm{C}$ represents the carbon stock in the soil (Bernoux, 1998). The coefficients represent the humification rate $\left(\mathrm{k}_{1}\right)$ decomposition rate $\left(\mathrm{k}_{2}\right)$, which are both driven by temperature, humidity, management practices and land cover type. This model presents standard errors between 5 and $10 \%$ for soil bulk density and this variation is smaller for ultisols than oxisols.

In the Brazilian state of Acre, soil carbon stocks down to $1 \mathrm{~m}$ depth vary from 52 to 110 $\mathrm{Mg} \mathrm{ha}^{-1}$, depending on soil type (Melo, 2003). These values however, were estimated based on multilinear regressions proposed by Bernoux (1998) which do not take into account changes in soil carbon dynamics due to changes in land use and land cover. 
SALIMON, C. I.; WADT, P. G. S.; ALVES, S. S. Decrease in carbon stocks in an oxisol due to land use and cover change in southwestern Amazon. Ambi-Agua, Taubaté, v. 4, n. 2, p. 57-65, 2009. (doi:10.4136/ambiagua.86)

For a more precise quantification of soil carbon stocks, it is also necessary to measure and estimate the stock variability among different land cover types in the same soil type, since even a slight variation, if significant, could imply in great differences in absolute values when extrapolated to a whole region, or when up scaling data in mathematical models.

Therefore, we propose in this paper to address the effect of land cover change and land cover use on the soil carbon stocks in a Ultisol of the Solimões Formation in western Amazonia, Acre - Brazil. For such purpose, we will be comparing three land cover types: mature forest, pastures and rubber tree plantation.

\section{MATERIAL AND METHODS}

The study was conducted in southwestern Amazonia, near the city of Rio Branco, at the EMBRAPA/ACRE experimental field station $\left(10^{\circ} 2.1^{\prime} \mathrm{S} ; 67^{\circ} 41.3^{\prime}\right)$. This part of the State has only $32 \%$ of its natural cover (INPE, 2008). Therefore, the eastern part of Acre is strongly impacted by land cover and land use change recently.

Native vegetation in western Amazônia is characterized as Ombrophilous Open Forest in the higher terrains, with a domination of Ombrophilous Dense Forest in the alluvial plains of larger rivers (RADAMBRASIL, 1976; ACRE, 2000). In a more detailed characterization, one can recognize areas where the Open Forest is dominated by the bamboo species Guadua weberbaueri Pilger (Silveira, 1999). Regional climate is classified as Am (Köpen) with its mean annual temperature $26^{\circ} \mathrm{C}$; annual precipitation varying from 1750 to $2000 \mathrm{~mm}$ (Duarte, 2006) with a well defined dry season from June to August and a mean annual relative air humidity of $85 \%$. Soil at the study sites is defined as Oxisol and in the Brazilian soil taxonomy it is classified as Red Dystrophic Mesoferric Latosol.

Carbon stocks were measured at three different land cover types: (1) mature forest, (2) rubber tree plantation (Hevea brasiliensis) planted 17 years ago, and (3) a 12 year old pasture of cultivated Brachiaria decumbens. Both rubber plantation and pasture were directly established after forest conversion, with no previous use. Therefore, the results presented hereon are only influenced by the land covers now extant.

At each land cover type we opened 3 trenches $(1.2 \times 1.2 \times 1.2 \mathrm{~m})$, from each soil samples were taken with a percussion sampler, using a Kopeck ring, at the following depths: 0-5, 5-10, $10-15,20-25,30-35,40-45,50-55,70-75$ and $90-95 \mathrm{~cm}$, totaling nine replicates per land cover type.

Each sample was taken to the lab, where firstly its volumetric water content was measured by weighing the wet and dry weight of a sub-sample, after 72 hours at $110^{\circ} \mathrm{C}$ in a forced circulation oven. Another sub-sample was dried at $60^{\circ} \mathrm{C}$ and then gently broken up and sieved. From this other sub-sample, we took $5 \mathrm{~g}$ of soil which was ground in a porcelain crucible and then $1 \mathrm{~g}$ was used for the determination of carbon content via oxidation with $\mathrm{K}_{2} \mathrm{Cr}_{2} \mathrm{O}_{7}$ in acidic medium with no external heating (EMBRAPA, 1997). For $\mathrm{pH}$ measurements, we used dried soil dissolved in water and for grain size was determined by dispersion with $\mathrm{NaOH}$ 1M (EMBRAPA, 1997).

Soil bulk density was directly determined by the Kopeck ring method, with a $98.07 \mathrm{~cm}^{3}$ cylinder $(5.28 \mathrm{~cm}$ height and $4.86 \mathrm{~cm}$ diameter). Each cylinder's soil sample was converted to dry weight and its density was expressed in $\mathrm{g} \mathrm{cm}^{-3}$. For a few samples where we did not have actual data on soil bulk density, these were calculated using the mathematical models proposed by Bernoux (1998) and Benites et al. (2007).

Carbon stocks were calculated by multiplying the soil carbon content at each depth by its soil bulk density, with results expressed in $\mathrm{Mg} \mathrm{ha}^{-1}$. Cumulative carbon stocks were calculated by adding each layers' values down to the lowest depth, which were respectively $5,10,17.5$, 
SALIMON, C. I.; WADT, P. G. S.; ALVES, S. S. Decrease in carbon stocks in an oxisol due to land use and cover change in southwestern Amazon. Ambi-Agua, Taubaté, v. 4, n. 2, p. 57-65, 2009. (doi:10.4136/ambiagua.86)

$27.5,37.5,47.5,62.5,82.5$ and $100 \mathrm{~cm}$. We then compared carbon stocks at each layer among the three different land cover types. We have also compared within each land cover type the carbon stock in different cumulative depths.

Comparisons among land cover types and soil depths were carried out by ANOVA and pos hoc Tukey test, at $10 \%$ significance). Same statistical procedures were done for soil bulk density at each depth and among land cover types. We used the statistical software SPSS 10.0 (SPSS, 1999).

\section{RESULTS AND DISCUSSION}

Soil bulk density under mature forest was greatest between 20 and $25 \mathrm{~cm}$ possibly due to a podzolization process, which tends to increase soil density; and its lowest value between 0 and $5 \mathrm{~cm}$ (Table 1), which could be due the influence of litter in the soil surface layer. On the other hand, soil bulk density under pasture was comparatively higher at $0-50 \mathrm{~cm}$, with lower values only at the deeper layers. The same trend described for pasture was observed for the rubber tree plantation, presenting lower densities at the deeper layers $(90$ to $95 \mathrm{~cm}$ depth, Table 1).

Table 1. Soil bulk density at different depths in mature forest, pasture and rubber tree plantation in an Oxisol in western Amazonia.

\begin{tabular}{|c|c|c|c|c|c|c|}
\hline \multirow{3}{*}{$\begin{array}{c}\text { Depth (cm) } \\
0-5\end{array}$} & \multicolumn{6}{|c|}{ Soil bulk density $\left(\mathrm{g} \mathrm{cm}^{-3}\right)$} \\
\hline & \multicolumn{2}{|c|}{ Mature forest } & \multicolumn{2}{|c|}{ Pasture } & \multicolumn{2}{|c|}{ Rubber tree plantation } \\
\hline & 0.99 & $\mathrm{cB}$ & 1.35 & abcA & 1.34 & abcA \\
\hline $5-10$ & 1.27 & $\mathrm{bB}$ & 1.50 & $\mathrm{aA}$ & 1.57 & $\mathrm{abA}$ \\
\hline $10-15$ & 1.31 & $\mathrm{bB}$ & 1.43 & $\mathrm{abcB}$ & 1.66 & $\mathrm{aA}$ \\
\hline $20-25$ & 1.38 & $\mathrm{aA}$ & 1.49 & $\mathrm{abA}$ & 1.46 & $\mathrm{abcA}$ \\
\hline $30-35$ & 1.19 & $\mathrm{bB}$ & 1.53 & $\mathrm{aA}$ & 1.39 & abcBA \\
\hline $40-45$ & 1.24 & $\mathrm{bC}$ & 1.48 & $\mathrm{abA}$ & 1.32 & $\mathrm{bcB}$ \\
\hline $50-55$ & 1.18 & $\mathrm{bcB}$ & 1.39 & abcA & 1.34 & $\mathrm{abcA}$ \\
\hline $70-75$ & 1.16 & $\mathrm{bcA}$ & 1.28 & $\mathrm{bcA}$ & 1.46 & abcA \\
\hline $90-95$ & 1.15 & $\mathrm{bcA}$ & 1.25 & $\mathrm{cA}$ & 1.22 & $\mathrm{cA}$ \\
\hline
\end{tabular}

Averages followed by the same lower case letter, in the same column are not different by Tukey test, at $10 \%$ significance. Averages followed by the same capital letter, in the same line, are not different by Tukey test, at 10\% significance.

When comparing these soil bulk densities, we observe that mature forest presented significantly lower density, specifically at the following layers 0 to 5,5 to 10,40 to 45 and 50 to $55 \mathrm{~cm}$ (Table 1). These data show that forest conversion to pasture and other agricultural purposes might result in an increase in soil bulk density down to a depth of $50 \mathrm{~cm}$.

Soil carbon content in mature forest was greatest down to $10 \mathrm{~cm}$, and from depth down it decreases and becomes fairly constant to $1 \mathrm{~m}$ depth (Table 2). In the pasture soil, carbon content was highest down to $15 \mathrm{~cm}$, probably due to the grasses dense root system, but from this depth down there is also a decrease in carbon content. Under rubber tree plantation only the first surface layer $(0$ to $5 \mathrm{~cm}$ ) was significantly higher then all the other layers (Table 2).

We observe from these results that the rubber tree plantation presented the lowest carbon content for all soil depths, which is an indication that this land cover (along with its agricultural practices and possible exposure of the soil prior to the plantation) has the lowest capacity to store carbon in the soil. On the other hand, pasture soil tended to increase carbon content from 0 to $35 \mathrm{~cm}$, and from this depth down tended to decrease its content to the point of presenting significantly less carbon than mature forest, and becoming not significantly different from rubber tree plantation. This trend in pasture is probably due to a shallower 
SALIMON, C. I.; WADT, P. G. S.; ALVES, S. S. Decrease in carbon stocks in an oxisol due to land use and cover change in southwestern Amazon. Ambi-Agua, Taubaté, v. 4, n. 2, p. 57-65, 2009. (doi:10.4136/ambiagua.86)

rizosphere than in forests, so below this depth, pasture soils begin to lose carbon due to the decomposition of older forest derived carbon.

Table 2 presents the organic carbon stock for each land cover. Pasture presented the greatest carbon stock from 0 to $5 \mathrm{~cm}$ and still presented the highest value from $10-15 \mathrm{~cm}$, which presented a cumulative stock of $1.5 \mathrm{Mg} \mathrm{ha}^{-1} \mathrm{~cm}^{-1}$. From this depth down, pasture soils presented less than $1 \mathrm{MgC} \mathrm{ha}^{-1} \mathrm{~cm}^{-1}$. Mature forest on the other hand, while presenting lower stocks at the surface layer, presented constantly more than $1 \mathrm{Mg} \mathrm{C} \mathrm{ha}^{-1} \mathrm{~cm}^{-1}$ down to $35 \mathrm{~cm}$ depth. The rubber tree plantation was the land cover type that presents the lowest values, and only the surface layer ( 0 to $5 \mathrm{~cm}$ ) had a stock greater than $1 \mathrm{Mg} \mathrm{ha}^{-1} \mathrm{~cm}^{-1}$.

Table 2. Soil carbon content $\left(\mathrm{dag} \mathrm{kg}^{-1}\right)$ as a function of depth and land cover type in an Oxisol in western Amazonia.

\begin{tabular}{|c|c|c|c|c|c|c|}
\hline \multirow{3}{*}{$\begin{array}{l}\text { Depth (cm) } \\
0-5\end{array}$} & \multicolumn{6}{|c|}{ Organic carbon (dag $\mathrm{kg}^{-1}$ ) } \\
\hline & \multicolumn{2}{|c|}{ Forest } & \multicolumn{2}{|c|}{ Pasture } & \multicolumn{2}{|c|}{ Rubber tree plantation } \\
\hline & 1.86 & $\mathrm{aA}$ & 1.86 & $\mathrm{aA}$ & 1.04 & $\mathrm{aB}$ \\
\hline $5-10$ & 1.19 & $\mathrm{bA}$ & 1.24 & $\mathrm{bA}$ & 0.59 & $\mathrm{bB}$ \\
\hline $10-15$ & 0.95 & $\mathrm{bcA}$ & 1.24 & $\mathrm{bA}$ & 0.45 & $\mathrm{bB}$ \\
\hline $20-25$ & 0.77 & $\mathrm{bcA}$ & 0.61 & $\mathrm{cAB}$ & 0.52 & $\mathrm{bC}$ \\
\hline $30-35$ & 0.76 & $\mathrm{bcA}$ & 0.57 & $\mathrm{cA}$ & 0.36 & $\mathrm{bB}$ \\
\hline $40-45$ & 0.82 & bcA & 0.39 & $\mathrm{cB}$ & 0.37 & $\mathrm{bB}$ \\
\hline $50-55$ & 0.64 & $\mathrm{cA}$ & 0.32 & $\mathrm{cB}$ & 0.41 & $\mathrm{bB}$ \\
\hline $70-75$ & 0.62 & $\mathrm{cA}$ & 0.31 & $\mathrm{cB}$ & 0.27 & $\mathrm{bB}$ \\
\hline $90-95$ & 0.72 & $\mathrm{cA}$ & 0.34 & $\mathrm{cB}$ & 0.33 & $\mathrm{bB}$ \\
\hline
\end{tabular}

Averages followed by the same lower case letter, in the same column are not different by Tukey test, at $10 \%$ significance. Averages followed by the same capital letter, in the same line, are not different by Tukey test, at $10 \%$ significance.

It is quite clear from these results that pasture has a greater capacity for storing carbon in the first $10 \mathrm{~cm}$ of soil when compared with mature forest and rubber plantation (Table 3). This greater stock may be due to a dense grass root system and also by a greater soil bulk density in this depth. Since the soil bulk density increase in pasture is probably due to soil compaction and erosion, this stock increase might be only apparent since there was a compression of soil layers. Nevertheless, since we have not specifically addressed the effect of soil compression, we did not take it into account in this study. So, we believe that these results are in fact caused by land cover type, and not by site specific characteristics, especially when soil compaction and erosion are common features found in pastures in several other studies made in the Amazon.

When we analyzed soil depths separately, the pasture soil presented the highest stocks down to $37.5 \mathrm{~cm}$. From this depth on, mature forest stocks presented the highest values. Except for the depth between 17.5 and $27.5 \mathrm{~cm}$, rubber tree plantation soils presented the significantly lower carbon stocks down to $1 \mathrm{~m}$ depth.

These differences in carbon stocks through soil depth show that pasture presents the greatest carbon stocks down to $30 \mathrm{~cm}$, where it holds $54 \%$ of its total stock down to $1 \mathrm{~m}$ (Table 4). From about 30 to $80 \mathrm{~cm}$ pasture and mature forest are not significantly different in terms of carbon stocks, but from 80 to $1 \mathrm{~m}$ mature forest accumulates significantly more carbon than pasture (Table 4). Rubber tree plantation presented significantly lower stocks for all depths.

Based on these findings, we suggest that the inflexion point between pasture and mature forest for the carbon accumulation in this type of Oxisol occurs roughly at $50 \mathrm{~cm}$ depth. This means that although pastures can accumulate carbon in the soil surface layers, they are probably losing carbon by decomposition of old dead trees' roots in the lower layers. 
SALIMON, C. I.; WADT, P. G. S.; ALVES, S. S. Decrease in carbon stocks in an oxisol due to land use and cover change in southwestern Amazon. Ambi-Agua, Taubaté, v. 4, n. 2, p. 57-65, 2009. (doi:10.4136/ambiagua.86)

In the light of the importance of carbon balance and sequestration in regional and global climate - and policy; these results are quite relevant, since studies that have addressed carbon stocks only down to $50 \mathrm{~cm}$ depth have demonstrated that pastures' soils are net sinks of carbon. Our study, on the contrary, show that down to $1 \mathrm{~m}$ depth pasture soils have significantly lost $17 \%$ of the mature forests original stock and rubber tree plantation has lost $41 \%$ of the original stock (Tukey, $10 \%$, Table 4 ). This implies that mature forest conversion to other land covers can be the source to the atmosphere of about 20 to $40 \%$ of the carbon stocked in the soil previously. Hence, we suggest that more research should be conducted to confirm (or not) that other rubber tree plantations also present the same pattern of decreasing soil carbon stocks.

Table 3. Soil carbon stocks as a function of soil depth and land cover type in an Oxisol in western Amazonia.

\begin{tabular}{lcccccc}
\hline Depth (cm) & \multicolumn{7}{c}{ Carbon stock $\left(\mathbf{M g ~ h}^{-\mathbf{1}}\right)$} \\
& Mature forest & Pasture & Rubber tree plantation \\
\hline $0-5$ & 9.1 & $\mathrm{~b}$ & 12.4 & $\mathrm{a}$ & 6.8 & $\mathrm{~b}$ \\
$5-10$ & 7.5 & $\mathrm{~b}$ & 9.1 & $\mathrm{a}$ & 4.7 & $\mathrm{c}$ \\
$10-17.5$ & 9.3 & $\mathrm{ab}$ & 12.6 & $\mathrm{a}$ & 5.5 & $\mathrm{~b}$ \\
$17.5-27.5$ & 10.6 & $\mathrm{a}$ & 8.9 & $\mathrm{a}$ & 7.5 & $\mathrm{a}$ \\
27.5 a 37.5 & 9.3 & $\mathrm{a}$ & 8.7 & $\mathrm{a}$ & 4.9 & $\mathrm{~b}$ \\
37.5 a 47.5 & 9.8 & $\mathrm{a}$ & 5.8 & $\mathrm{~b}$ & 4.8 & $\mathrm{~b}$ \\
47.5 a 62.5 & 11.3 & $\mathrm{a}$ & 6.7 & $\mathrm{~b}$ & 7.9 & $\mathrm{~b}$ \\
62.5 a 82.5 & 14.4 & $\mathrm{a}$ & 8.0 & $\mathrm{~b}$ & 6.8 & $\mathrm{~b}$ \\
82.5 a 100 & 14.5 & $\mathrm{a}$ & 7.3 & $\mathrm{~b}$ & 7.3 & $\mathrm{~b}$ \\
\hline
\end{tabular}

Averages followed by the same lower case letter, in the same line, are not different by Tukey test, at $10 \%$ significance.

The greater carbon stock in the first $30 \mathrm{~cm}$ of soil in pasture has also been observed by other authors for southwestern Amazon (Salimon et al., 2004; Moraes et al., 1996) and has also been predicted in carbon balance models such as Century and Rothamstead $\mathrm{C}$ for well managed and not degraded pastures (Cerri et al., 2007a, 2007b). These results could be explained partially by the high photosynthetic rate in these $\mathrm{C} 4$ grasses. This effect, however, is not observed below $50 \mathrm{~cm}$, where the decay of old carbon becomes a net loss under pasture, meanwhile due to the high tree diversity in mature forest, there is a deeper rooting system still alive, allowing the soil to stock more carbon in depth.

Table 4. Cumulative soil carbon stock as a function of depth and land cover type in an Oxisol in western Amazonia.

\begin{tabular}{ccccccc}
\hline Depth (cm) & \multicolumn{6}{c}{ Cumulative organic carbon $\left(\mathbf{M g} \boldsymbol{C ~ h a} \boldsymbol{~}^{-1}\right)$} \\
& Forest & \multicolumn{3}{c}{ Pasture } & Rubber tree plantation \\
\hline 5 & 9.1 & $\mathrm{~b}$ & 12.4 & $\mathrm{a}$ & 6.8 & $\mathrm{~b}$ \\
10 & 16.6 & $\mathrm{~b}$ & 21.5 & $\mathrm{a}$ & 11.4 & $\mathrm{c}$ \\
17.5 & 25.9 & $\mathrm{~b}$ & 34.1 & $\mathrm{a}$ & 17.0 & $\mathrm{c}$ \\
27.5 & 36.6 & $\mathrm{~b}$ & 43.1 & $\mathrm{a}$ & 24.5 & $\mathrm{c}$ \\
37.5 & 45.9 & $\mathrm{a}$ & 51.7 & $\mathrm{a}$ & 29.4 & $\mathrm{~b}$ \\
47.5 & 55.7 & $\mathrm{a}$ & 57.6 & $\mathrm{a}$ & 34.2 & $\mathrm{~b}$ \\
62.5 & 67.0 & $\mathrm{a}$ & 64.3 & $\mathrm{a}$ & 42.1 & $\mathrm{~b}$ \\
82.5 & 81.5 & $\mathrm{a}$ & 72.4 & $\mathrm{a}$ & 49.0 & $\mathrm{~b}$ \\
100 & 96.0 & $\mathrm{a}$ & 79.7 & $\mathrm{~b}$ & 56.3 & $\mathrm{c}$ \\
\hline
\end{tabular}

Averages followed by the same lower case letter, in the same line, are not different by Tukey test, at $10 \%$ significance. 
SALIMON, C. I.; WADT, P. G. S.; ALVES, S. S. Decrease in carbon stocks in an oxisol due to land use and cover change in southwestern Amazon. Ambi-Agua, Taubaté, v. 4, n. 2, p. 57-65, 2009. (doi:10.4136/ambiagua.86)

Total carbon stocks down to $1 \mathrm{~m}$ depth for all three land covers were inferior to values reported by Wadt (2005) for an Alfisol under pasture and agricultural use in this same locality. Salimon et al. (2007) estimated the carbon stocks down to $60 \mathrm{~cm}$ depth as 33 to $45 \mathrm{Mg} \mathrm{ha}^{-1}$ in mature forests, 38 to $44 \mathrm{Mg} \mathrm{ha}^{-1}$ for secondary forests and 50 a $64 \mathrm{Mg} \mathrm{ha}^{-1}$ for pastures. These values are all within the same order of magnitude of the ones presented in the present study for pastures, but lower for mature forests. It is worth mentioning though that Salimon et al. (2007) have worked on soils rich in high activity clays, which tend to be shallower and lesser pedological development, which could explain the lower carbon stocks in deeper layers of soil, mainly under mature forests.

A soil carbon stock estimate made for the whole state of Acre (Melo, 2003) indicate that soil carbon stocks down to $1 \mathrm{~m}$ depth range from 52 to $110 \mathrm{Mg} \mathrm{ha}^{-1}$, where Ultisols alone range from 58 to $68 \mathrm{Mg} \mathrm{ha}^{-1}$. These values, specifically the ones for Ultisols are lower than the ones presented here, and only similar to the ones found for rubber tree plantation. Nevertheless, it is important to notice that the method used by Melo (2003) was prone to systematic errors due to the lack of soil bulk density values for most of the soils and more specifically for the ones with high CEC. Yet, one would expect that for Ultisols with low CEC this would not be a problem, unless the equations used by Melo (2003) are not applicable even to low CEC Ultisols in Acre State.

Finally, the present study indicates the great need for more studies addressing the issues presented so far, before researchers opt for multivariate equations for soil carbon stocks estimates in the Amazon. In addition, these mathematical models do not take into account land cover type, which we show in this paper to be significant drivers of soil carbon stocks and are a great source of variability.

\section{CONCLUSIONS}

Although pasture presented greater carbon stock on surface layers of soil, total soil carbon stock accumulated down to $1 \mathrm{~m}$ depth was greatest in mature forest $\left(96 \mathrm{Mg} \mathrm{ha}^{-1}\right)$, then followed by pasture $\left(79.7 \mathrm{Mg} \mathrm{ha}^{-1}\right.$ ) and by rubber tree plantation (56.3 $\mathrm{Mg} \mathrm{ha}^{-1}$ ). These findings suggest that not only carbon stocks vary due to land cover type, but it also varies through depth within land cover type.

Although great mathematical tools for estimating carbon stocks, multilinear regressions should include the effect of land cover type in soil carbon dynamics, even through depth, otherwise they can overestimate total carbon stocks after deforestation, since mature forest conversion to other land covers can be the source to the atmosphere of about 20 to $40 \%$ of the carbon stocked in the soil previously.

Therefore, we suggest more research in this field, with more replicates at different land cover types in order to estimate more precisely the influence of land cover type on carbon stocks. Also, we need more accurate information on land cover types through remote sensing techniques, for scaling up regional carbon stocks.

\section{ACKNOLEDGEMENTS}

We would like to thank Andreas Krimkiff for help during field work and CNPq/PIBIC scholarship for Suhelen de Souza Alves.

\section{REFERENCES}

ACRE (Estado). Zoneamento ecológico-econômico do estado do Acre. Rio Branco: Governo do Estado do Acre, 2000. 
BENITES, V.M.; MACAHADO, P.L.A.; FIDALGO, E.C.C.; COELHO, M.R.; MADARI, B.E. Pedotransfer functions for estimating soil bulk density from existing soil survey reports in Brazil. Geoderma, v. 139, p. 90-97, 2007.

BRADY, N. C.; WEIL, R. R. The nature and properties of soils. 12. ed. Upper Saddle River: Prentice Hall, 1999. 881p.

BERNOUX, M. Conteúdo de carbono dos solos da Amazônia ocidental e mudanças decorrentes da conversão da floresta em pastagens. 1998. 98f. Tese (Doutorado em Ciências Agrárias) - Centro de Energia Nuclear na Agricultura, Universidade de São Paulo, Piracicaba, 1998.

CARVALHO, M. C. S.; ANDRADE, C. A . de; MELTI, A . J.; CERRI, C. C. Soil carbon stocks influenced by litter and roots quality on pasture chronosequence in Rondônia. In: CONFERÊNCIA CIENTÍFICA INTERNACIONAL DO EXPERIMENTO LBA, 2., 710 julho 2002, Manaus. Abstracts... São José dos Campos: INPE, 2002.

CERRI, C. E. P.; EASTER, M.; PAUSTIAN, K.; KILLIAN, K.; COLEMAN, K.; BERNOUX, M. et al. Predicted soil organic carbon stocks and changes in the Brazilian Amazon between 2000 and 2030. Agriculture Ecosystems \& Environment, v. 122, n. 1, p. 58-72, 2007a.

CERRI, C. E. P.; EASTER, M.; PAUSTIAN, K.; KILLIAN, K.; COLEMAN, K.; BERNOUX, M. et al. Simulating SOC changes in 11 land use change chronosequences from the Brazilian Amazon with RothC and Century models. Agriculture Ecosystems \& Environment, v. 122, n. 1, p. 46-57, 2007b.

CERRI, C. C.; BERNOUX, M.; ARROUAYS, D.; FEIGL, B. J.; PICCOLO, M. C. Carbon stocks in soil of the brazilian Amazon. In: LAL, R.; KIMBLE, J. M.; STEWART, B. A. (EDS.). Global climate change and tropical ecosystems.Boca Raton: CRC, , 199. p. 33-50. (Advances in soil Science)

DUARTE, A. F. Aspectos da climatologia do Acre, Brasil, com base no intervalo 1971 2000. Revista Brasileira de Meteorologia, v. 21, n. 3b, p. 308-317, 2006.

EMPRESA BRASILEIRA DE PESQUISA AGROPECUÁRIA - EMBRAPA. Métodos da análises químicas e físicas de solos e plantas. Rio de Janeiro: Embrapa Solos, 1997. $112 \mathrm{p}$.

ESWARAN, H.; BERG, E. van D.; REICH, P. Organic carbon in soils of the world. Soil Sci. Soc. Am. J., v. 57, n. 1, p. 192-194, 1993.

INSTITUTO NACIONAL DE PESQUISAS ESPACIAIS. Projeto PRODES: monitoramento da floresta amazônica brasileira por satélite. Disponível em: $<$ http://www.obt.inpe.br/prodes/index.html>. Acesso em: 15 out. de 2008.

MANRIQUE, L. A.; JONES, C. A. Bulk density of soils in relation to soil physical and chemical properties. Soil Sci. Soc. Am. J., v. 55, p. 476-481, 1991.

MELO, A. W. F. de. Avaliação do estoque e composição isotópica do carbono do solo no Acre. 2003. 74f. Dissertação (Mestrado em Ecologia de Agroecossistemas) - Escola Superior de Agricultura "Luiz de Queiroz", Universidade de São Paulo, São Paulo, 2003. 
MORAES, J. F. L.; VOLKOFF, B.; CERRI, C. C. et al. Soil properties under Amazon forest and change due to pasture installation in Rondonia, Brazil. Geoderma, v. 70, p. 63-81, 1996.

RADAMBRASIL. Folha SC.19 Rio Branco. . Rio de Janeiro: Projeto RadamBrasil, 1976.

SALIMON, C. I; WADT, P. G. S.; MELO, A. W. F. Dinâmica do carbono na Conversão de Floresta para Pastagens em Argissolos da Formação Geológica Solimões, no Sudoeste da Amazônia. Revista de Biologia e Ciências da Terra, v. 7, n. 1, p. 29-38, 2007.

SALIMON, C. I.; DAVIDSON, E. A.; VICTORIA, R. L.; MELO, A. W. F. CO flux from soil in pastures and forests in southwestern Amazonia. Global Change Biology, v. 10, p. 833-843, 2004.

SCHLESINGER, W. H. Biogeochemistry: an analysis of global change. Boston: Academic Press, 1997.

SILVEIRA, M. Ecological aspects of bamboo-dominated Forest in southwestern Amazônia: an ethnoscience perspective. Ecotropica, v. 5, p. 213-216, 1999.

SPSS. Statistical Package for the Social Sciences Advanced Models 10.0. Chicago: SPSS, 1999.

WADT, P. G. S. Estoque de carbono em um Plintossolo Argilúvico da formação Solimões, Amazônia, Brasil. Rio Branco: Embrapa Acre, 2005. 15p. (Boletim Informativo). 